\title{
Materials and Compositions for Enhancing the Load Capacity of Structural-Unstable Soils
}

\author{
Kharchenko I.Ya. \\ Institute of Construction and Architecture \\ Moscow State University of Civil Engineering \\ Moscow, Russia \\ iharcenko@mail.ru \\ Nakhayev M.R. \\ Vice-rector in Scientific Work \\ Chechen State University \\ Faculty of Construction \\ Grozny State Oil Technical University named \\ M.D. Millionshikova, Grozny, Russia \\ mr-nakhaev@mail.ru
}

\author{
Murtazayev S-A.Yu. \\ Department of Materials Science \\ Kh. Ibragimov Complex Institute of the RAS, \\ Department of Technical Sciences \\ Academy of Sciences of Chechen Republic, \\ Faculty of Construction \\ Grozny State Oil Technical University named \\ M.D. Millionshikova, Grozny, Russia \\ s.murtazaev@mail.ru
}

Ismailova Z.Kh.

Faculty of Construction

Grozny State Oil Technical University

named after M.D. Millionshikova

Grozny, Russia

Ismailova-Z-H@mail.ru

\author{
Abukhanov A.Z. \\ Faculty of Construction \\ Grozny State Oil Technical University named M.D. Millionshikova \\ Grozny, Russia \\ abuhanov54@mail.ru
}

\begin{abstract}
The work is devoted to effective ways to increase the load capacity of buildings bases and structures by impregnating soils with compounds based on complex finely dispersed binder and local raw materials. The article shows that an important factor in the effective injection fixation of structural-unstable soils is the penetrating ability of the solution characterized by viscosity and sedimentation, depending on the composition of the complex binder. It allows to improve the antifiltration properties of the reinforced massifs, resistance to various aggressive effects, speed of strength gain, etc.
\end{abstract}

Keywords $\rightarrow$ soil settlement, building basements, structuralunstable soils, technogenic raw materials, soil consolidation, injection compounds, Mikrodur, soil load capacity

\section{INTRODUCTION}

It is known that one of the most crucial technological conversions during building is the basement and structure construction. To ensure the safety of construction objects, construction basement should be based on sound data from studies of the base soil properties, especially in cases where the soil layer is composed of structurally unstable, weak water-saturated and other problematic soils [1].

It is taken for granted that bases composed of similar soils cannot be operated without a definite transformation, prior improvement of their properties, for which different methods of soil consolidation are used. Using of various methods depend on the technology, chemical processes occurring in the soil during injection of solutions and the changes nature in the soil properties [2-5].

The most effective method of preventing uneven sediments and subsequent deformations of buildings and structures, as shown by the experience of Russian and foreign scientists [5$8]$, is the injection fixing of the soils. Injection reinforcement of structural-unstable soils provides an increase of their load capacity, water resistance, durability and strength.

The main factor of effective injection fixation is the penetrating ability of the solution, characterized by viscosity and sedimentation $[5,7,9]$.

Viscosity and stability (sedimentation) of the injection solution are dependent on its water-binding ratio $(\mathrm{V} / \mathrm{V})$, the method of preparation and the chemical additives. The main parameters of the study were the viscosity, sedimentation and setting time of the injection solution, which are regulated by $\mathrm{V} / \mathrm{V}$, time and intensity of solution mixing, as well as plasticizing additives. It should be noted that the most important factor determining the solution is $\mathrm{V} / \mathrm{V}$, which depends on the composition of the used complex fine binder. 


\section{Methods AND MATERIALS}

Research methods are based on the theory of clinker minerals hardening with fillers of various genesis, for example, local substandard very fine sand, carbonate flour and cement dust. Mathematical logic and technology of composite materials are used as methods also. The studies were carried out considering current state standards and recommendations.

The main component of the complex fine binder (CFB) is a particularly finely dispersed substance Mikrodur ${ }^{\circledR}$ (ECFD Mikrodur $\left.{ }^{\circledR}\right)$. As a filler for CFB, raw materials were studied (Table 1). They were finely ground, so it made possible to obtain a solution with enough penetration to fix the soil. Numerous works [10-13] are known, stating the effectiveness of using local raw materials, including those of technogenic origin, in the technology of concrete and mortar.

Table 1 shows that the closest materials to ECFB Mikrodur ${ }^{\circledR}$ by dispersiveness are the following materials: cement dust, carbonate flour obtained by grinding limestone, and silica fume. However, it should be noted that with the proper selection of the solution composition, each of these materials can be used as a component for the preparation of the CFB.

To obtain the corresponding indicators of dispersion, some of the materials used were floured by roller mill MLR-15 in a laboratory for a certain time: sand and volcanic ash for 30 minutes, and limestone for 40 minutes. Continuation of grinding, above the specified time, did not show better results.

TABLE I. PROPERTIES OF MATERIAL USED

\begin{tabular}{|c|c|c|c|c|}
\hline No & Material Used & $\begin{array}{c}\text { Power } \\
\mathbf{d e n s i t y , ~} \boldsymbol{\rho}, \\
\mathbf{g} / \mathbf{c m}^{\mathbf{3}}\end{array}$ & $\begin{array}{c}\text { Specific } \\
\text { Surface, } \\
\boldsymbol{S}_{\mathbf{S S}},{\mathbf{~} \mathbf{m}^{2} \mathbf{g}}^{\mathbf{g}}\end{array}$ & $\begin{array}{c}\text { Time of } \\
\text { Flouring, } \\
\mathbf{\text { min }}\end{array}$ \\
\hline 2 & $\begin{array}{c}\text { Cement Dust (Chiri- } \\
\text { Yrt, Chechen } \\
\text { Republic) }\end{array}$ & 3.1 & 12100 & - \\
\hline 2 & $\begin{array}{c}\text { Limestone (Shatoyskiy } \\
\text { district, Chechen } \\
\text { Republic) }\end{array}$ & 2.62 & 9200 & 40 \\
\hline 4 & $\begin{array}{c}\text { Sand (Vedeno, } \\
\text { Chechen Republic) }\end{array}$ & 2.6 & 5250 & 30 \\
\hline 5 & $\begin{array}{c}\text { Sand (Chervlennaya, } \\
\text { Chechen Republic) }\end{array}$ & 2.65 & 4950 & 30 \\
\hline 6 & $\begin{array}{c}\text { Sand (Tolstoy-Yurt, } \\
\text { Chechen Republic) }\end{array}$ & 2.55 & 5000 & 30 \\
\hline 7 & $\begin{array}{c}\text { Volcanic Ash } \\
\text { (Nalchik) }\end{array}$ & 2.60 & 6800 & 30 \\
\hline 8 & $\begin{array}{c}\text { Silica Fume } \\
\text { (Novokuznetsk) }\end{array}$ & 2.20 & 12150 & - \\
\hline 9 & $\begin{array}{c}\text { Silica Fume } \\
\text { (Chelyabinsk) }\end{array}$ & 2.25 & 12400 & - \\
\hline
\end{tabular}

One of the reasons for the loess soil settlement is the aggregates particles' ability of these soils to peptize when they are wet. Other words, to the transition of solid colloidal crystals into a liquid solution; high rates of $\mathrm{V} / \mathrm{V}$ solutions for fixing such soils are extremely undesirable. However, this problem has been proposed to be solved with the help of additives and fine-dispersed local raw materials used as a filler.

\section{RESULTS}

According to the data of sedimentation analysis of solutions for local raw materials, these materials in their own form have a large percentage of water separation, except for silica fume and cement dust (Table 2). However, the viscosity indices of these materials indicate a high penetrating ability, since the flow time of solutions through the Marsh Viscometer at $\mathrm{V} / \mathrm{V}=4$ is $\leq 32 \mathrm{~s}$ for the proposed raw material, based on Mikrodur ${ }^{\circledR}-39 \mathrm{~s}$. This suggests that due to these properties of solutions based on Mikrodur ${ }^{\circledR}$ and local raw materials, it is possible to adjust the composition of injection solutions through their integrated use.

TABLE II. INDICATORS OF VISCOSITY AND SEDIMENTATION OF LOCAL RAW MATERIALS

\begin{tabular}{|c|c|c|c|c|c|c|c|c|c|c|}
\hline \multirow{2}{*}{ No } & \multirow{2}{*}{ Material } & \multirow{2}{*}{$\stackrel{n}{i}$} & \multicolumn{8}{|c|}{ Sedimentation in time (minutes), $\%$} \\
\hline & & & 15 & 30 & 45 & 60 & 75 & 90 & 120 & 150 \\
\hline 1 & Cement Dust & 28 & 10.8 & 18.8 & 22.8 & 27.2 & 34.0 & 34.4 & 35.2 & 35.2 \\
\hline 2 & Limestone & 29 & 17.4 & 24.6 & 32.8 & 37.4 & 43.0 & 45.4 & 46.4 & 46.4 \\
\hline 3 & $\begin{array}{c}\text { Sand (Vedeno, } \\
\text { Chechen } \\
\text { Republic) }\end{array}$ & 30 & 32.4 & 45.2 & 52.8 & 55.8 & 57.4 & 59.6 & 60.4 & 61.8 \\
\hline 4 & $\begin{array}{c}\text { Sand } \\
\text { (Chervlennaya, } \\
\text { Chechen } \\
\text { Republic) }\end{array}$ & 29 & 61.2 & 70.6 & 70.4 & 72.0 & 72.4 & 73.2 & 73.2 & 73.2 \\
\hline 5 & $\begin{array}{l}\text { Sand (Tolstoy- } \\
\text { Yurt, Chechen } \\
\text { Republic) }\end{array}$ & 30 & 42.0 & 57.2 & 59.6 & 61.6 & 63.2 & 64.4 & 64.4 & 64.4 \\
\hline 6 & Volcanic Ash & 29 & 58.8 & 63.6 & 65.6 & 68.2 & 69.6 & 70.0 & 70.0 & 70.0 \\
\hline 7 & $\begin{array}{c}\text { Silica Fume } \\
\text { (Novokuznetsk) }\end{array}$ & 31 & 12.0 & 21.2 & 29.4 & 30.2 & 32.8 & 35.2 & 37.2 & 38.0 \\
\hline 8 & $\begin{array}{c}\text { Silica Fume } \\
\text { (Chelyabinsk) }\end{array}$ & 32 & 4.0 & 7.2 & 9.6 & 13.6 & 16.0 & 18.8 & 25.2 & 25.6 \\
\hline
\end{tabular}

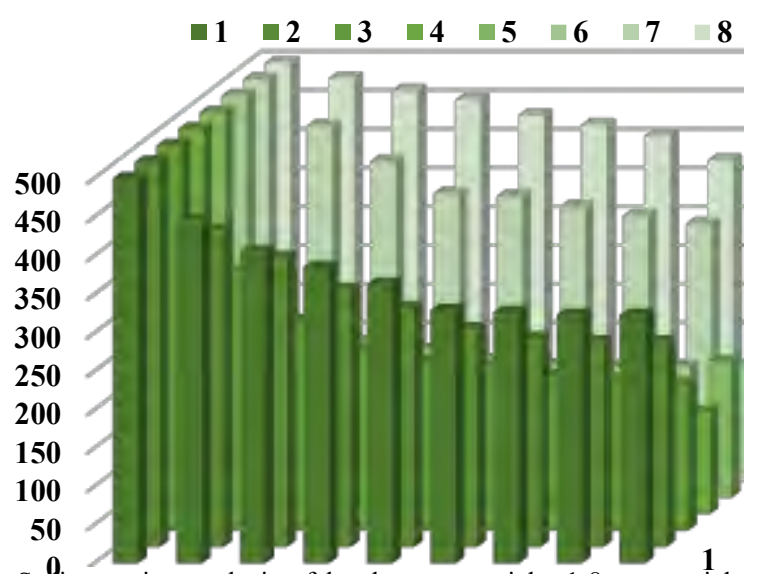

Fig. 1. Sedimentation analysis of local raw materials: 1-8 - materials used according to Table 2 .

Thus, considering the obtained data, the compositions of solutions based on CFB (Mikrodur ${ }^{\circledR}+$ filler) at $\mathrm{V} / \mathrm{V}=4$ were selected, while maintaining the stability of the solution and the required viscosity. Below, in Tables 3-10 the viscosity and sedimentation of solutions based on CFB are presented at different ratios of Mikrodur $\AA$ and finely dispersed local raw materials: 20/80, 30/70, 40/60, 50/50. 
TABLE III. INDICATORS OF VISCOSITY AND SEDIMENTATION OF CFB'S COMPOSITIONS BASED ON CEMENT DUST (CD)

\begin{tabular}{|c|c|c|c|c|c|c|c|c|c|}
\hline \multirow{2}{*}{$\begin{array}{c}\text { Ration } \\
\text { CFB/CD, \% }\end{array}$} & \multirow{2}{*}{ Viscosity, s } & \multicolumn{6}{|c|}{ Sedimentation in time (minutes), \% } \\
\cline { 3 - 10 } & & $\mathbf{1 5}$ & $\mathbf{3 0}$ & $\mathbf{4 5}$ & $\mathbf{6 0}$ & $\mathbf{7 5}$ & $\mathbf{9 0}$ & $\mathbf{1 2 0}$ & $\mathbf{1 5 0}$ \\
\hline $20 / 80$ & 29 & 8 & 22 & 36 & 49 & 54.5 & 56 & 57 & 57.5 \\
\hline $30 / 70$ & 30 & 0 & 12 & 16 & 22 & 28 & 31 & 32 & 33 \\
\hline $40 / 60$ & 33 & 0 & 0.5 & 11 & 14 & 16 & 16.5 & 17 & 17.5 \\
\hline $50 / 50$ & 35 & 0 & 0 & 8 & 12 & 13 & 14.5 & 15.5 & 16 \\
\hline
\end{tabular}

TABLE IV. INDICATORS OF VISCOSITY AND SEDIMENTATION OF CFB'S COMPOSITIONS BASED ON LIMESTONE (LS)

\begin{tabular}{|c|c|c|c|c|c|c|c|c|c|}
\hline \multirow{2}{*}{$\begin{array}{c}\text { Ratio CFB/LS, } \\
\%\end{array}$} & \multirow{2}{*}{$\begin{array}{c}\text { Viscosity, } \\
\text { s }\end{array}$} & \multicolumn{6}{|c|}{ Sedimentation in time (minutes), \% } \\
\cline { 3 - 11 } & & $\mathbf{1 5}$ & $\mathbf{3 0}$ & $\mathbf{4 5}$ & $\mathbf{6 0}$ & $\mathbf{7 5}$ & $\mathbf{9 0}$ & $\mathbf{1 2 0}$ & $\mathbf{1 5 0}$ \\
\hline $20 / 80$ & 30 & 18 & 36 & 44 & 57 & 59 & 59.5 & 60 & 61 \\
\hline $30 / 70$ & 31 & 0 & 12 & 26 & 34 & 38 & 41.5 & 42 & 42 \\
\hline $40 / 60$ & 34 & 0 & 1 & 11 & 18 & 25 & 28 & 35 & 37 \\
\hline $50 / 50$ & 36 & 0 & 0.5 & 10 & 15.5 & 18 & 26 & 28 & 31 \\
\hline
\end{tabular}

TABLE V. INDICATORS OF VISCOSITY AND SEDIMENTATION OF CFB'S COMPOSITIONS BASED ON SAND (VEDENO, CHECHEN REPUBliC) ( $\mathrm{S}_{\mathrm{V}}$ )

\begin{tabular}{|c|c|c|c|c|c|c|c|c|c|}
\hline \multirow{2}{*}{$\begin{array}{c}\text { Ration CFB/ } \\
\text { SV, \% }\end{array}$} & Viscosity, & \multicolumn{6}{|c|}{ Sedimentation in time (minutes), \% } \\
\cline { 3 - 11 } & $\mathbf{s}$ & $\mathbf{1 5}$ & $\mathbf{3 0}$ & $\mathbf{4 5}$ & $\mathbf{6 0}$ & $\mathbf{7 5}$ & $\mathbf{9 0}$ & $\mathbf{1 2 0}$ & $\mathbf{1 5 0}$ \\
\hline $20 / 80$ & 31 & 18 & 33 & 42 & 51 & 54 & 57 & 59 & 60 \\
\hline $30 / 70$ & 32 & 0 & 19 & 28 & 31 & 35 & 38 & 39 & 40 \\
\hline $40 / 60$ & 35 & 0 & 0 & 6.5 & 12 & 19.5 & 22 & 25 & 28 \\
\hline $50 / 50$ & 37 & 0 & 0 & 1.5 & 5 & 10 & 15 & 18 & 22 \\
\hline
\end{tabular}

TABLE VI. INDICATORS OF VISCOSITY AND SEDIMENTATION OF CFB'S COMPOSITIONS BASED ON SAND (CHERVLENNAYA, CHECHEN REPUBLIC) $\left(\mathrm{S}_{\mathrm{CH}}\right)$

\begin{tabular}{|c|c|c|c|c|c|c|c|c|c|}
\hline \multirow{2}{*}{$\begin{array}{c}\text { Ratio } \\
\text { CFB/SCH, \% }\end{array}$} & \multirow{2}{*}{$\begin{array}{c}\text { Viscosity, } \\
\text { s }\end{array}$} & \multicolumn{6}{|c|}{ Sedimentation in time (minutes), \% } \\
\cline { 3 - 11 } & & $\mathbf{1 5}$ & $\mathbf{3 0}$ & $\mathbf{4 5}$ & $\mathbf{6 0}$ & $\mathbf{7 5}$ & $\mathbf{9 0}$ & $\mathbf{1 2 0}$ & $\mathbf{1 5 0}$ \\
\hline $20 / 80$ & 31 & 21 & 44 & 48 & 57 & 59 & 60 & 60,5 & 61 \\
\hline $30 / 70$ & 33 & 0 & 22 & 31 & 34 & 39 & 42 & 43 & 43 \\
\hline $40 / 60$ & 36 & 0 & 1 & 11 & 20 & 27 & 29 & 32 & 34 \\
\hline $50 / 50$ & 37 & 0 & 0 & 10 & 16 & 19 & 23 & 25 & 27 \\
\hline
\end{tabular}

TABLE VII. INDICATORS OF VISCOSITY AND SEDIMENTATION OF CFB's COMPOSITIONS BASED ON SAND (TOLSTOY-YURT, CHECHEN REPUBLIC) $\left(\mathrm{S}_{\text {TY }}\right)$

\begin{tabular}{|c|c|c|c|c|c|c|c|c|c|}
\hline \multirow{2}{*}{$\begin{array}{c}\text { Ratio } \\
\text { CFB/ }\end{array}$} & \multirow{2}{*}{$\begin{array}{c}\text { Viscosity, } \\
\text { s }\end{array}$} & \multicolumn{6}{|c|}{ Sedimentation in time (minutes), \% } \\
\hline & & $\mathbf{1 5}$ & $\mathbf{3 0}$ & $\mathbf{4 5}$ & $\mathbf{6 0}$ & $\mathbf{7 5}$ & $\mathbf{9 0}$ & $\mathbf{1 2 0}$ & $\mathbf{1 5 0}$ \\
\hline $20 / 80$ & 32 & 24 & 38 & 45 & 60 & 61 & 61,5 & 62 & 62 \\
\hline $30 / 70$ & 34 & 10 & 25 & 33 & 37 & 44 & 46 & 48 & 49 \\
\hline $40 / 60$ & 37 & 1 & 11 & 19 & 28 & 37 & 39 & 40 & 41 \\
\hline $50 / 50$ & 38 & 0 & 2 & 10 & 18 & 19 & 24 & 27 & 30 \\
\hline
\end{tabular}

TABLE VIII. INDICATORS OF VISCOSITY AND SEDIMENTATION OF CFB'S COMPOSITIONS BASED ON VOLCANIC ASH (VA)

\begin{tabular}{|c|c|c|c|c|c|c|c|c|c|}
\hline \multirow{2}{*}{$\begin{array}{c}\text { Ratio } \\
\text { CFB/VA, \% }\end{array}$} & \multirow{2}{*}{$\begin{array}{c}\text { Viscosity, } \\
\text { s }\end{array}$} & \multicolumn{9}{|c|}{ Sedimentation in time (minutes), \% } \\
\cline { 2 - 11 } & & $\mathbf{1 5}$ & $\mathbf{3 0}$ & $\mathbf{4 5}$ & $\mathbf{6 0}$ & $\mathbf{7 5}$ & $\mathbf{9 0}$ & $\mathbf{1 2 0}$ & $\mathbf{1 5 0}$ \\
\hline $20 / 80$ & 30 & 19 & 43 & 46 & 47 & 48 & 49 & 49.5 & 50 \\
\hline $30 / 70$ & 32 & 0 & 19 & 28 & 35 & 38 & 39 & 40 & 41 \\
\hline $40 / 60$ & 35 & 0 & 0.5 & 5.5 & 12 & 17 & 22 & 25 & 28 \\
\hline $50 / 50$ & 37 & 0 & 0 & 0.5 & 8 & 12 & 15 & 20 & 23 \\
\hline
\end{tabular}

TABLE IX. INDICATORS OF VISCOSITY AND SEDIMENTATION OF CFB'S COMPOSITIONS BASED ON SILICA FUME (NOVOKUZNETSK) $\left(\mathrm{SF}_{\mathrm{N}}\right)$

\begin{tabular}{|c|c|c|c|c|c|c|c|c|c|}
\hline \multirow{2}{*}{$\begin{array}{c}\text { Ratio CFB/ } \\
\text { SF }_{\mathbf{N}} \%\end{array}$} & $\begin{array}{c}\text { Viscosity, } \\
\text { s }\end{array}$ & \multicolumn{6}{|c|}{ Sedimentation in time (minutes), \% } \\
\cline { 2 - 11 } & & $\mathbf{1 5}$ & $\mathbf{3 0}$ & $\mathbf{4 5}$ & $\mathbf{6 0}$ & $\mathbf{7 5}$ & $\mathbf{9 0}$ & $\mathbf{1 2 0}$ & $\mathbf{1 5 0}$ \\
\hline $20 / 80$ & 32 & 14 & 23 & 29 & 36 & 42 & 45 & 48 & 52 \\
\hline $30 / 70$ & 34 & 0 & 16.5 & 25 & 28 & 33 & 39 & 40 & 40.5 \\
\hline $40 / 60$ & 37 & 0 & 0.5 & 9 & 16 & 21 & 25 & 27 & 29 \\
\hline $50 / 50$ & 39 & 0 & 0 & 0 & 8 & 12.5 & 15 & 19 & 21 \\
\hline
\end{tabular}

TABLE $\mathrm{X}$. INDICATORS OF VISCOSITY AND SEDIMENTATION OF CFB's COMPOSITIONS BASED ON SILICA FUME (CHELYABINSK) $\left(\mathrm{SF}_{\mathrm{CH}}\right)$

\begin{tabular}{|c|c|c|c|c|c|c|c|c|c|}
\hline \multirow{2}{*}{$\begin{array}{c}\text { Ratio CFB/ } \\
\text { SF }_{\mathbf{C H},}, \mathbf{\%}\end{array}$} & \multirow{2}{*}{$\begin{array}{c}\text { Viscosity, } \\
\text { S }\end{array}$} & \multicolumn{6}{|c|}{ Sedimentation in time (minutes), \% } \\
\cline { 3 - 11 } & & $\mathbf{1 5}$ & $\mathbf{3 0}$ & $\mathbf{4 5}$ & $\mathbf{6 0}$ & $\mathbf{7 5}$ & $\mathbf{9 0}$ & $\mathbf{1 2 0}$ & $\mathbf{1 5 0}$ \\
\hline $20 / 80$ & 33 & 7 & 16 & 24 & 29 & 35 & 38 & 42 & 45 \\
\hline $30 / 70$ & 35 & 0 & 2 & 11 & 17 & 24 & 26 & 32 & 35 \\
\hline $40 / 60$ & 38 & 0 & 0 & 0 & 5 & 10 & 14 & 20 & 23 \\
\hline $50 / 50$ & 39 & 0 & 0 & 0 & 0 & 3 & 8 & 12 & 15 \\
\hline
\end{tabular}

According to the data obtained, the viscosity of the solutions CFB are in the following intervals:

- at a ratio of Mikrodur ${ }^{\circledR}$ : filler 20/80 - 29-32 s;

- the same, at $30 / 70-30-35 \mathrm{~s}$;

- the same, at $40 / 60-33-38 \mathrm{~s}$;

- the same, at 50/50 - 35-39 s.

Such viscosity indices represent the possibility of reducing the Mikrodur ${ }^{\circledR}$ TRAF by $50-80 \%$. Also, as a result of the research, the strength of the hardened stone was determined at the age of 28 days, which was formed as a result of the hardening of the CFB solution (Table 11). For this purpose, a mortar mixture of normal thickness was prepared (as in the cement test) with a lower V/V from 0.4 to 1.0 . Hardening of the samples was carried out at $20^{\circ} \mathrm{C}$ and relative humidity of 60-70\%. The Preparation of CFB solutions, with a Mikrodur ${ }^{\circledR}$ content of more than $50 \%$ of the total mass, was not appropriate, due to the high cost of this material. Reducing the expensive imported product by $50-80 \%$ will give a good economic effect, and domestic raw materials will make it more popular and competitive in the global construction market.

TABLE XI. COMPRESSIVE STRENGHT OF HARD CFB IN WATERASTRINGENT ATTITUDE

\begin{tabular}{|c|c|c|c|c|}
\hline № & $\begin{array}{c}\text { Ratio CFB / } \\
\text { Filler, \% }\end{array}$ & Filler Sort & $\begin{array}{c}\text { Water- } \\
\text { Astringent } \\
\text { Attitude }\end{array}$ & $\begin{array}{l}\text { Compressive } \\
\text { Strength, MPa }\end{array}$ \\
\hline \multirow{4}{*}{1} & \multirow{4}{*}{$50 / 50$} & \multirow{4}{*}{ Cement Dusk } & 0.4 & 82.3 \\
\hline & & & 0.6 & 79.5 \\
\hline & & & 0.8 & 75.1 \\
\hline & & & 1.0 & 71.8 \\
\hline \multirow{4}{*}{2} & \multirow{4}{*}{$50 / 50$} & \multirow{4}{*}{ Limestone } & 0.4 & 62.2 \\
\hline & & & 0.6 & 60.1 \\
\hline & & & 0.8 & 58.2 \\
\hline & & & 1.0 & 55.8 \\
\hline \multirow{4}{*}{3} & \multirow{4}{*}{$50 / 50$} & \multirow{4}{*}{$\begin{array}{c}\text { Sand (Vedeno, } \\
\text { Chechen } \\
\text { Republic) }\end{array}$} & 0.4 & 45.1 \\
\hline & & & 0.6 & 43.7 \\
\hline & & & 0.8 & 41.3 \\
\hline & & & 1.0 & 38.9 \\
\hline
\end{tabular}




\section{CONCLUSION}

According to the research results, it was found that the viscosity and sedimentation rates of all the materials studied are almost the same. It proves the viability of each of them in injection solutions as a filler together with Mikrodur ${ }^{\circledR}$

As a result of the research, materials and compositions for fixing structural-unstable soils are proposed. The main rheological properties (water separation, viscosity and setting time) of the CSB were determined and the optimal compositions of composites based on them were proposed.

\section{References}

[1] V.V. Annenkov. Technology development for the installation of foundations and basements of reconstructed buildings on weak soils. Moscow: GASIS, 2008

[2] A. Arsan, Improving the technology of strengthening the soils of the foundations of buildings and structures. Technical Sciences Cand. Diss. Kharkov, 2005.

[3] G.A. Bobyr', Optimization of hardened arrays parameters in the grounds, composed of structurally unstable soils.Technical Sciences Cand. Diss. Moscow, 2002.

[4] A.Z. Abukhanov, V.Kh. KHadisov, M.R. Nakhayev, "Injection technology of soil consolidation of building bases." Innovative technologies in production, science and education. Proceedings of the II International Scientific and Practical Conference, pp. 19-25, 2012.

[5] M.R. Nakhayev, Composite compounds with finely divided filler for injecting various genesis anchoring soil subsidence. Technical Sciences Cand. Diss. Makhachkala, 2015.

[6] S.-A.Yu. Murtazayev, M.R. Nakhayev, I.Ya. Kharchenko, "Injection consolidation of loess soils by CFB (Mikrodur) in Grozny," Bulletin of Dagestan State Technical University, 4, pp. 123-129, 2014
[7] I.Ya. Kharchenko, S.-A.Yu. Murtazayev, M.R. Nakhayev, "The compositions of the CFB for injection fixation of soils with a complex filler of various genesis", Ecology and Industry of Russia, 3, pp. 48-52, 2015 .

[8] S.-A.Yu. Murtazayev, A.Z. Abukhanov, M.R. Nakhayev, "Features of the use of extremely finely dispersed substances of the type "Microdur" for injection fixing of soils," Materials of the All-Russian Scientific and Practical Conference "Science and Education in the Chechen Republic: State and Prospects" dedicated to the 10th anniversary of the foundation of the Scientific Research Institute of the Russian Academy of Sciences. Grozny. pp. 187-191, 2015.

[9] I.Ya. Kharchenko, S.A.Yu. Murtazayev, A.Z. Abukhanov, M.R. Nakhayev, "Optimization of the composition of the Microdur ECFB with complex fillers of natural and man-made origin," Modern building materials, technology and construction. Materials of the International Scientific and Practical Conference dedicated to the 95th anniversary of Acad. Md Millionshchikov. Grozny State Oil Technical University named after Academician MD Millionshchikov, pp. 223-234, 2015.

[10] Yu.I. Potapova, "High-rise construction in Russia - problems, tasks and solutions," Successes of modern science, 6, pp. 14-16, 2012.

[11] Yu.Yu. Galkin, S.A. Udodov, L.V. Vasil'eva, "The phase composition and properties of aluminate cements after early loading," Engineering and Construction Journal, 7 (75), pp. 114-122, 2012.

[12] M.Sh. Salamanova, M.S. Saydumov, T.S.A. Murtazayeva, "High-quality modified concretes based on mineral additives and superplasticizers of various nature." Innovation and investment, 8, pp. 163-166, 2015.

[13] M.S. Saydumov, A.S. Uspanova, S.A. Aliyev, "Ecological materials science problems of using technogenic waste in post-crisis areas," Science of the XXI century. Problems of academic mobility of the researcher and research methodology Materials of the II International Scientific Practical Conference. Edited by Z.A. Demchenko, pp. 440 443, 2012. 